\title{
MULTIDISCIPLINARY APPROACH FOR THE ASSESSMENT OF COASTAL RISKS AT CLOUGHANINCHY (WEST COAST OF IRELAND)
}

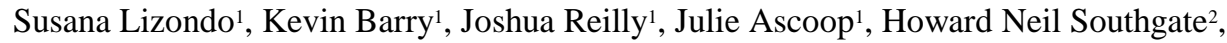 \\ Matilda Kitou ${ }^{2}$, Daniel Walsh ${ }^{1}$, Steve Lahiffe ${ }^{3}$ and Tom Tiernan ${ }^{3}$.
}

\begin{abstract}
The purpose of this paper is to present the multidisciplinary approach adopted to undertake a detailed coastal flood and erosion risk management investigation at Cloughaninchy beach (Ireland). The site was severely affected by a series of extreme events with extreme high tide combined with a severe sea swell and onshore winds resulting in severe damage due to flooding and wave action as well as substantial retreat of the dune system. Based on a comprehensive assessment and multidisciplinary studies an appropriate plan was subsequently developed to best manage the risks identified and to further assess the feasibility of the recommended management plan options and measures. The project is an example of how vital the integration of specialized disciplines (coastal engineering, hydraulic flood modelling and coastal morphology) is in the determination of the appropriate protection measures for coastal sites.
\end{abstract}

Keywords: coastal flood; coastal risk management; overtopping; optioneering; cost-benefit analysis

\section{INTRODUCTION}

\section{Background}

In January 2014 significant areas of the west coast of Ireland were subject to severe coastal storm events. On Friday morning, 3 January 2014 a combination of high tide, substantial sea swell and extreme onshore winds resulted in severe damage to the naturally occurring coastal protection infrastructure at Cloughaninchy beach, Co. Clare. This was further exacerbated by an event of similar characteristics but slightly lesser magnitude 3 days later on 6 January 2014. A similar event occurred on 1 February but the extent of the damage was reduced due to the construction of emergency coastal defences by Clare Co. Co. in between the 6 January and 1 February events (See Fig.1).

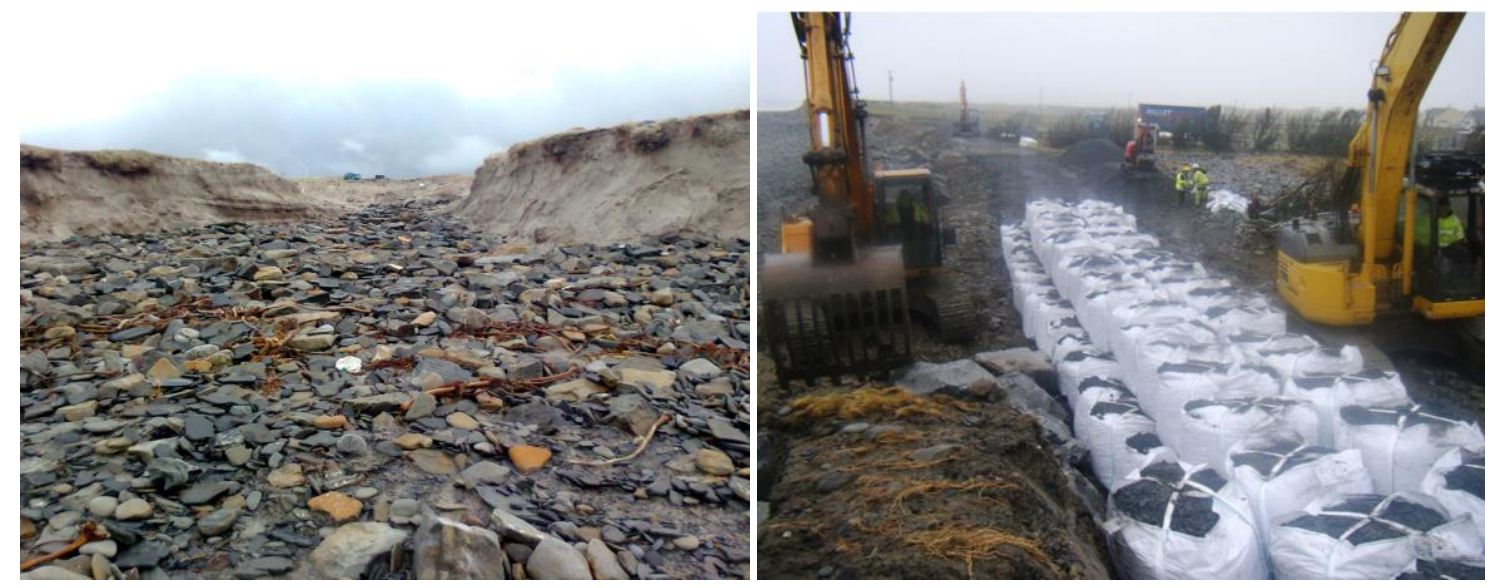

Figure 1. Breach in dunes system in the north (left) and emergency repair work being undertaken on the coastal embankment in the south (right) .Photographs provided by Clare County Council.

This study describes the multidisciplinary studies undertaken to assess the coastal risks and develop an appropriate solution and management plan for the site. These studies included: wave propagation modeling, tidal flood modeling including overtopping, erosion, fluvial influence, optioneering, coastal management plan and cost-benefit analysis. This study is the first of its kind in Ireland to be carried out to the Office of Public Works (OPW) scope and terms of reference for coastal works.

\footnotetext{
${ }^{1}$ Maritime Department, Arup, 50 Ringsend Road, Dublin, D04 T6X0, Ireland

${ }^{2}$ Maritime Department, Arup, 13 Fitzroy St, London W1T 4BQ, UK

${ }^{3}$ Roads and transport Department, Clare County Council, New Ennis Road, Ennis, Co. Clare, Ireland
} 


\section{Description of the site}

The study area is a $2 \mathrm{~km}$ coastal area located on the West coast of Ireland and consists of a natural dune system, sandy beach and natural shingle surrounded by rock outcrops (Fig. 2). The dune system was severely affected by the aforementioned storm resulting in severe damage due to flooding and wave action as well as substantial retreat of the dune system. There are a number of residential properties at the site as well as a pumping station and local roads. A natural embankment runs along the Western boundary of the site as indicated by the blue line in Figure 2. The embankment is characterised by a natural dune system in the northern section of the site (indicated by the top photograph in Figure 2) and a Clougher (local shingle) embankment in the southern section of the site. Following the storm damage in January 2014 Clare County Council constructed emergency coastal works at the southern section consisting of a rock revetment made up of rock armour and fill material.

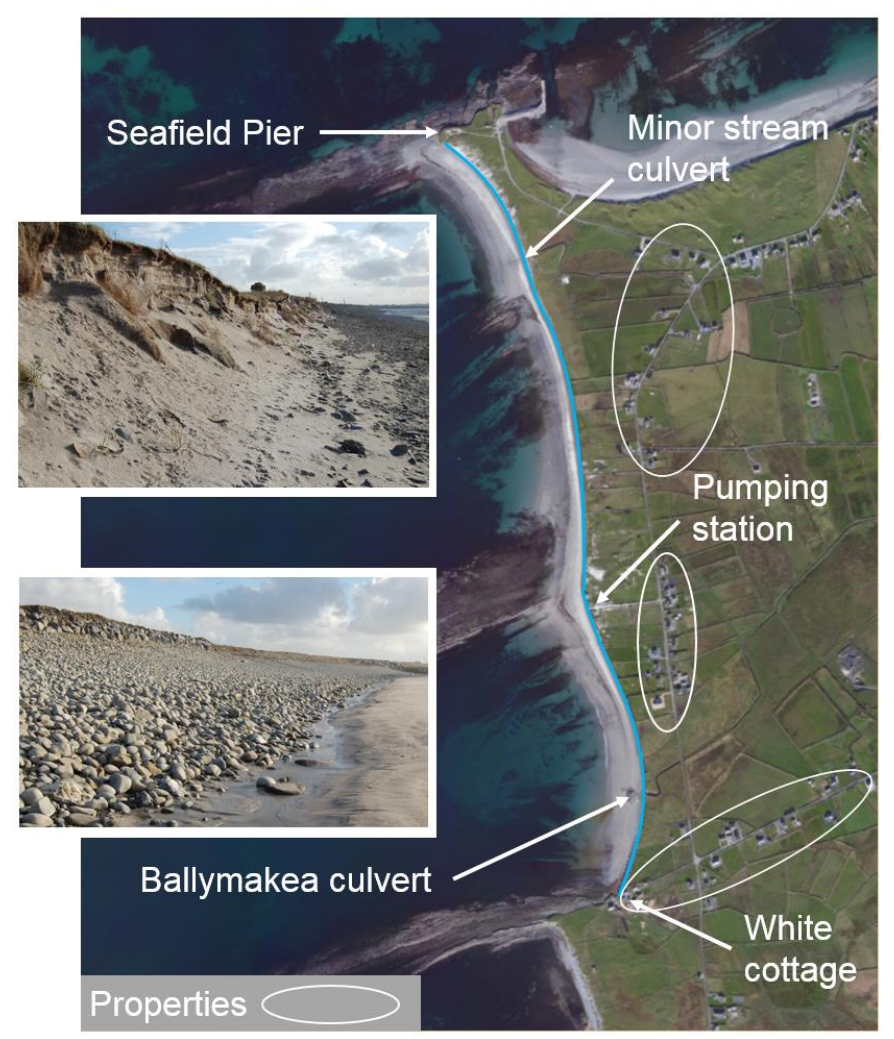

Figure 2. Cloughaninchy area of study.

\section{METHODOLOGY}

\section{Surveys and assessment of existing information}

A number of detailed high-resolution datasets were collected in order to construct the hydrodynamic, spectral wave and coastal evolution models. These include: (1) LiDAR data, (2) topographic data, (3) nearshore and offshore bathymetric data and (4) sediment sampling. Existing data included (5) tide gauge data, (6) extreme sea levels from the Irish Coastal Protection Strategy Study (ICPSS) and (7) specific information of the storm events.

\section{LiDAR}

A high resolution LiDAR survey of the site was undertaken in order to capture the spatially-varying floodplain elevations. The point density of the data is approximately 4 points per $\mathrm{m}^{2}$ per flight line. The vertical accuracy is $\pm 12 \mathrm{~cm}$ while the horizontal accuracy is $\pm 24 \mathrm{~mm}$ on hard well defined surfaces. An image of the Cloughaninchy LiDAR coverage is presented in Figure 3. 
Figure 3. LiDAR dataset.

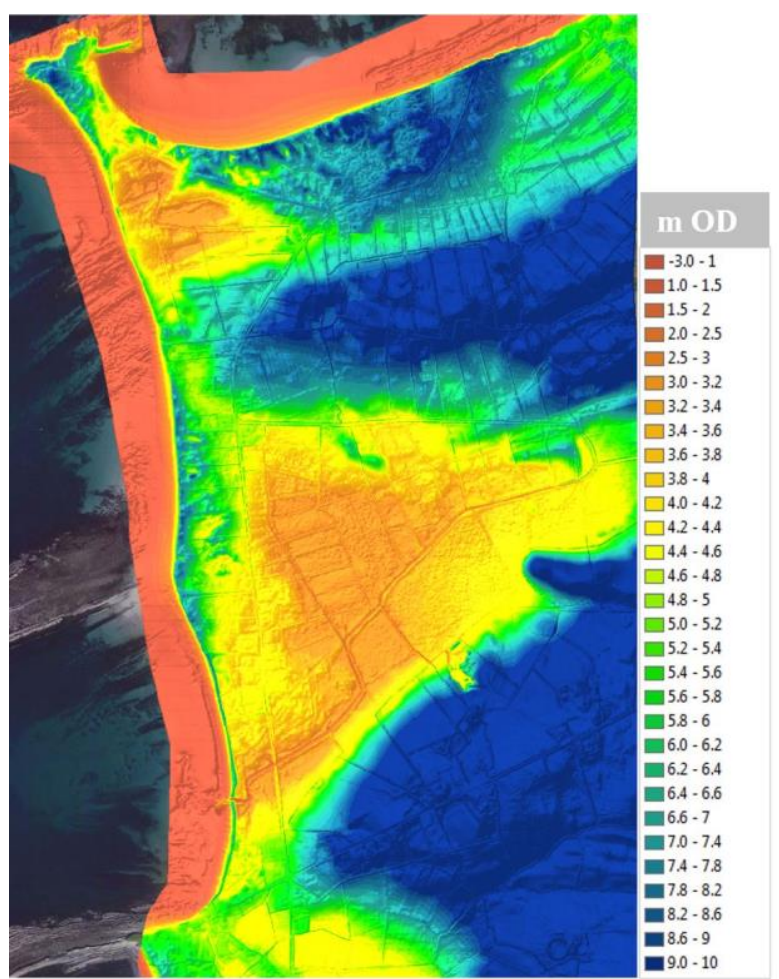

2. Topographic data

A topographic survey was undertaken to determine the ground elevations of the beach and nearshore areas as well as the crest level of the embankment. Data was also recorded for the two rivers which discharge onto the beach. High water marks from the 2014 flood event indicated on post flood event photographs were also recorded as part of the survey. Dimensions and elevations of all existing structures were also gathered.

3. Nearshore and offshore bathymetric datasets

The bathymetric survey was gathered using a single beam echo sounder survey undertaken with a CeeducerPro. The gathered data was combined with existing offshore bathymetric data from different the integrated mapping for the sustainable development of Ireland's marine resource (INFOMAR) surveys to provide an overall dataset of the bathymetry adjacent to the site.

4. Sediment sampling

A sediment sampling campaign was undertaken to obtain sediment size data for the model in the emerged beach.

5. Tide gauge data

Tide gauge data was sourced from the Marine Institute, Shannon Foynes Port Company and Electricity Supply Board Ireland (ESBI) for a number of gauges around the West coast of Ireland. The data was used to estimate the severity of the January 2014 event and to provide a tidal curve for the tidal boundary conditions of the site.

6. ICPSS Study

The Irish Coastal Protection Strategy Study (ICPSS) developed by the OPW, provides predictions of extreme sea levels for a number of return period events for various locations around the Irish coast. This data was used in the study to derive the extreme tidal water level (astronomical plus surge) boundary conditions at the site. The ICPSS extreme water levels were also used to estimate the severity of the January 2014 event.

7. Previous flood events

Photographs and video footage of the storm events of 2014 were provided by Clare County Council. This information was used to understand the extent of the damage and flooding caused by the event. 


\section{Numerical models}

Detailed numerical modelling studies were developed to assess the various risks at the site. These models include: 1) MIKE 21 Spectral Wave model of both the nearshore and offshore area to assess wave influence on both flooding and coastal erosion, 2) MIKE 21 HD coastal flood model where wave overtopping discharges were incorporated into the 2D model, 3) 1D ISIS hydraulic river model and 4) MIKE 21 Litpack model to assess sediment transport.

1. Spectral wave model

The spectral wave propagation model was developed using MIKE 21 Spectral Wave (SW). This is a 3rd generation spectral wind-wave software produced by the Danish Hydraulic Institute (DHI) that simulates the growth, decay and transformation of wind-generated waves and swells in offshore and coastal areas.

Offshore wind and wave data for the model was obtained from the Marine Institute weather buoy network. Data was statistically assessed using CAROL v1.0 software, which was created by the Ocean and Coastal Research Group (GIOC) of the University of Cantabria (Spain).
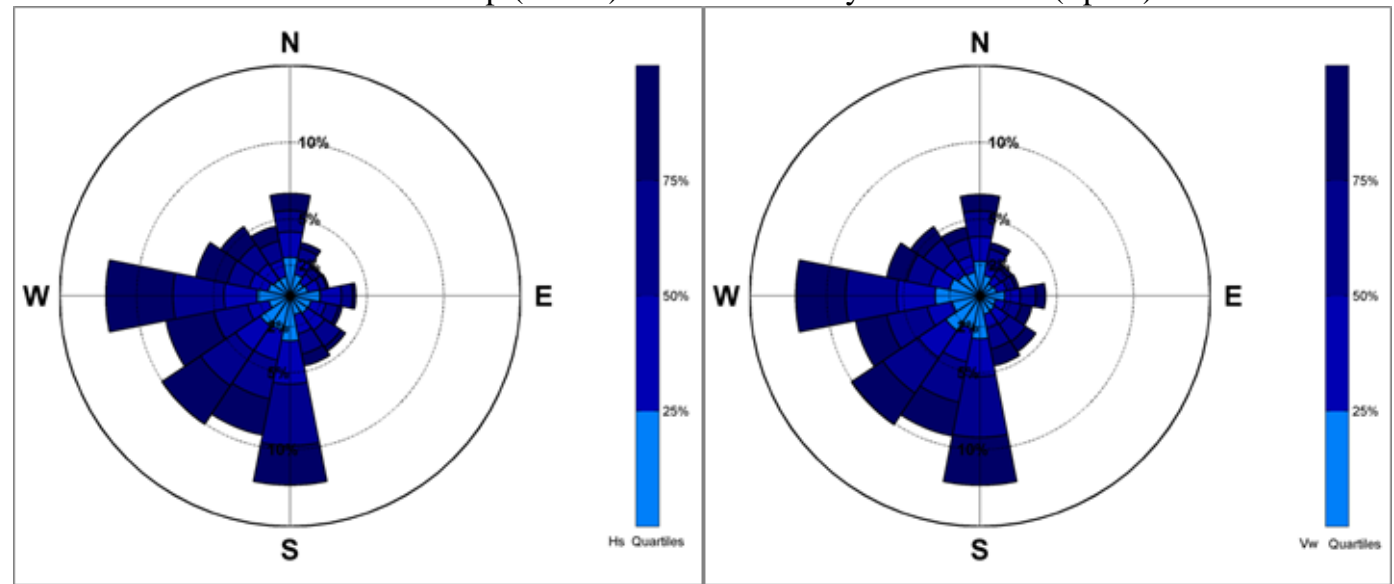

Figure 4. Offshore wave (left) and wind (right) roses

A number of different extreme water levels were analysed for the SW and W direction. The final water levels adopted for the wave modelling incorporated three different scenarios as follows: the current scenario, the Mid-Range Future Scenario (MRFS) and the High-End Future Scenario (HEFS). These scenarios included for sea level rise where applicable. Final water levels included for storm surge and extreme tidal water level combined with Mean High Water Springs (MHWS). Extreme water levels for a range of Annual Exceedance Probabilities (AEP) (10\%, 0.5\% and 0.1\%) as derived in the ICPSS were adopted for the model. This model was also used to inform the engineering design of the solutions for the study area.

2. 2D Hydrodynamic flood model including wave overtopping

The model has been developed using the flexible mesh (FM) version of MIKE 21 HD developed by the DHI. The model calculates the time varying water levels and current velocities on an irregular grid of nodes throughout the model domain.

Table 1 presents a complete list of the design model cases. 


\begin{tabular}{|c|c|c|c|c|}
\hline \multicolumn{5}{|c|}{ Coastal Flood maps } \\
\hline $\begin{array}{c}\text { Map } \\
\text { No }\end{array}$ & Scenario & Mechanism & Type & Return period $\operatorname{Tr}$ (years) \\
\hline 1 & Current & Tidal & $\begin{array}{l}\text { Flood extent } \\
\text { map }\end{array}$ & 10,200 and 1000 \\
\hline 2 & Current & Tidal & Flood depth map & 10 \\
\hline 3 & Current & Tidal & Flood depth map & 200 \\
\hline 4 & Current & Tidal & Flood depth map & 1000 \\
\hline 5 & Current & $\begin{array}{c}\text { Wave overtopping+ } \\
\text { Tidal }\end{array}$ & $\begin{array}{c}\text { Flood extent } \\
\text { map }\end{array}$ & 10,200 and 1000 \\
\hline 6 & Current & $\begin{array}{l}\text { Wave overtopping+ } \\
\text { Tidal }\end{array}$ & Flood depth map & 10 \\
\hline 7 & Current & $\begin{array}{c}\text { Wave overtopping+ } \\
\text { Tidal }\end{array}$ & Flood depth map & 200 \\
\hline 8 & Current & $\begin{array}{c}\text { Wave overtopping+ } \\
\text { Tidal }\end{array}$ & Flood depth map & 1000 \\
\hline 9 & MFRS Scenario & Tidal & $\begin{array}{l}\text { Flood extent } \\
\text { map }\end{array}$ & 10,200 and 1000 \\
\hline 10 & MFRS Scenario & $\begin{array}{c}\text { Wave overtopping+ } \\
\text { Tidal }\end{array}$ & $\begin{array}{l}\text { Flood extent } \\
\text { map }\end{array}$ & 10,200 and 1000 \\
\hline 11 & $\begin{array}{c}\text { Breach Scenario with } 2 \\
\text { locations }\end{array}$ & Tidal + Breaches & $\begin{array}{l}\text { Flood extent } \\
\text { map }\end{array}$ & 10,200 and 1000 \\
\hline
\end{tabular}

A detailed assessment of the risk of wave overtopping at the site and a specific methodology to include the overtopping into the models was developed as part of the study. Wave overtopping volumes were first estimated using a detailed methodology, and these were subsequently included in the 2D hydrodynamic model as multiple source discharge points. For this, the empirical formulations in the Eurotop manual and CIRIA Rock Manual were used to estimate volumes of overtopping in litres per second per metre length of embankment. The nearshore wave heights, embankment geometry and various overtopping parameters were used in these calculations.

Through a detailed assessment of the various datasets available on the January 2014 event and a close inspection of the LiDAR dataset coupled with site visits, it was determined that wave overtopping was the primary source of flooding during the January 2014 event. Significant volumes of water overtopped the embankment and flooded the site.

The overtopping was exacerbated by the formation of breaches through the embankment which succeeded in lowering the crest elevation, in turn leading to greater volumes of wave overtopping. Figure 5 presents the extent for the tide + wave overtopping + breach scenario. It can be seen that a number of the houses are indicated as being at risk of flooding for this scenario. The location of the breaches in the model were selected based on a detailed inspection of the embankment which considered likely breach locations given the current state of the embankment. 


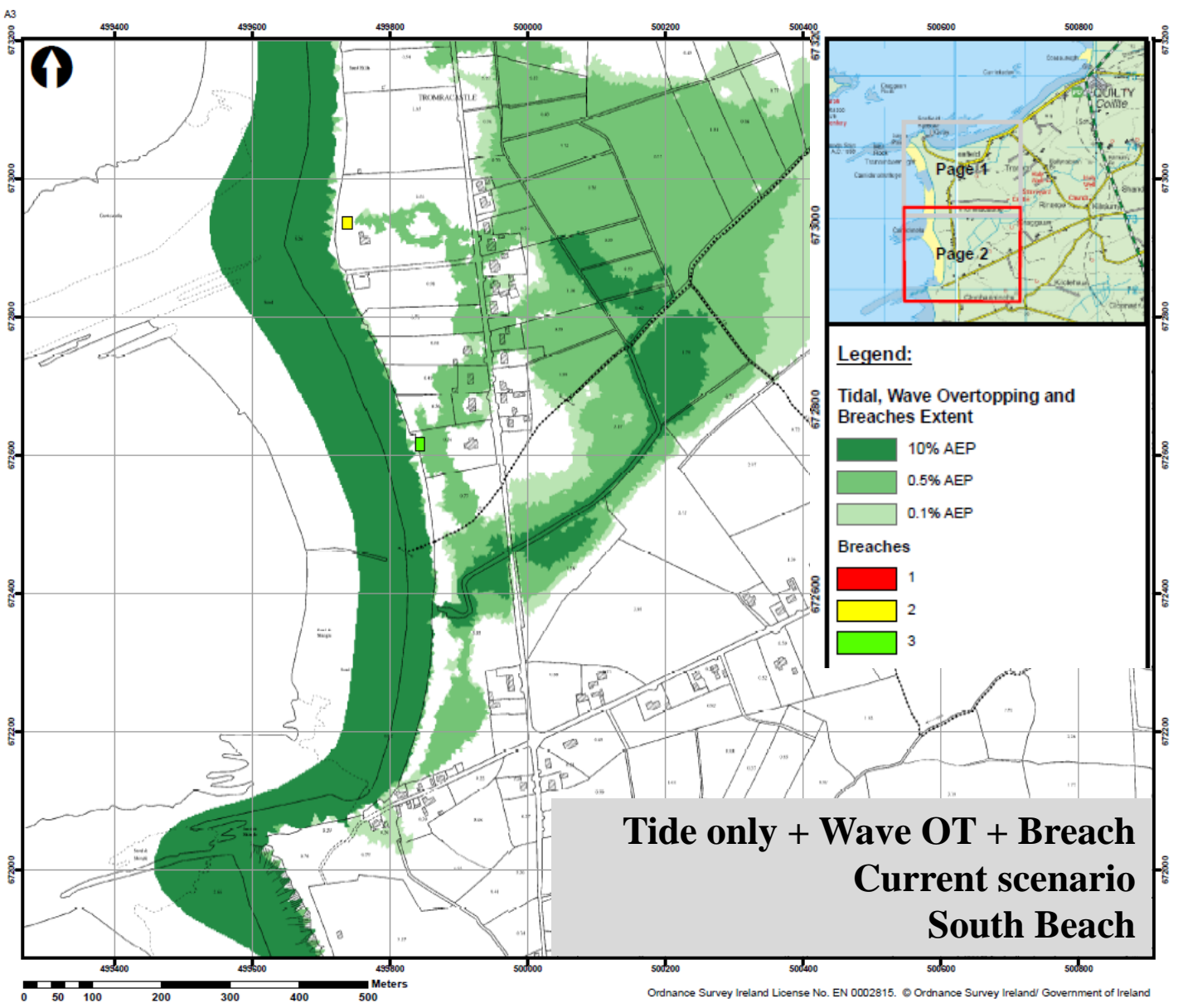

Figure 5. Flood extent map for the South Beach: Current Scenario, tide + wave overtopping + breach.

It is noted that the breaches do not lead to tidal inundation of the site as the existing ground levels behind the embankment at the breach locations are elevated above the level of the return period events considered. The flooding that occurs through the breach is the result of wave overtopping volumes.

3. 1D Hydraulic river model

A detailed 1D hydraulic model of the River Ballymakea was developed as part of the feasibility study. The model was developed in ISIS Professional v3.5 and simulates the time varying water and flows in response to design hydrographs. Hydraulic flooding was identified as a secondary source of flooding.

4. Coastal evolution model

MIKE 21 Litpack Flexible Mesh (FM) model was used to assess the coastal evolution. LITPACK is a numerical model in MIKE software package, developed by DHI, for simulating non-cohesive sediment transport in wave and currents, littoral drift, coastline evolution and profile development along quasi-uniform beaches.

Average wave conditions from the spectral wave model were given as input to the model. The $\mathrm{D}_{50}$ value varied between $0.3 \mathrm{~mm}$ and $0.35 \mathrm{~mm}$ across the cross sections.

The coastline erosion rates obtained are shown in Table 2.

\begin{tabular}{|l|l|l|}
\hline \multicolumn{3}{|l|}{ Table 2. Coastline recession rates. } \\
\hline Year & Average Recession & Maximum Recession \\
\hline 1 year & $0.4 \mathrm{~m}$ & $1.0 \mathrm{~m}$ \\
\hline 2050 & $14 \mathrm{~m} \mathrm{CR}+10 \mathrm{~m} \mathrm{SLR}=24 \mathrm{~m}$ & $35 \mathrm{~m}+10 \mathrm{~m}$ SLR $=45 \mathrm{~m}$ \\
\hline 2100 & $34 \mathrm{~m}+20 \mathrm{~m} \mathrm{SLR}=54 \mathrm{~m}$ & $85+20 \mathrm{~m}$ SLR $=105 \mathrm{~m}$ \\
\hline
\end{tabular}




\section{Coastal processes}

1. Physiographic unit

Cloughaninchy beach is limited by two long rock outcrops which form a sub-physiographic unit. These rock outcrops limit the beach and prevent the area from accelerated erosion. Three different sediment transport cells have been identified in the area (see Figure 6).

The coastal areas to the south of Cloughaninchy beach provide a potential source of sediment to the area of study. However, the existence of the rock outcrop to the south of the area of study limits the potential movement and re-nourishment of material from the south to the Cloughaninchy beach. There is no potential source of material coming from the north, since the adjoining areas to the north are protected by a pier and located to the east of the coastline of study.

2. Historical evolution

The shape of the beach has been constant over the years that there are records available for, suggesting that dynamic equilibrium or close to dynamic equilibrium state was reached.

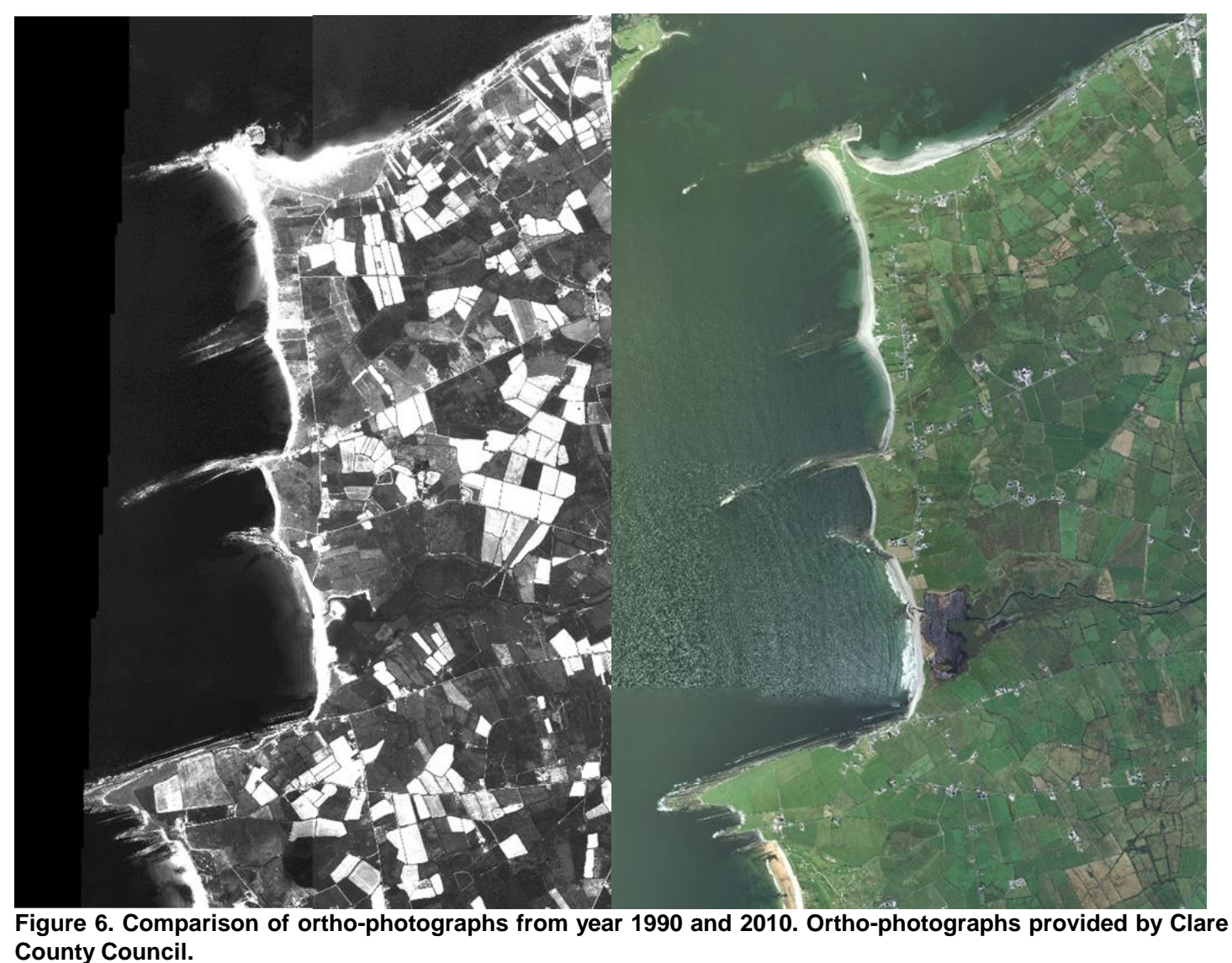

3. Assessment

Based on the physiographic unit, historical evidence and the modelling carried out the following conclusions can be drawn:

- Based on the results of the model, historical evolution and wave conditions it was concluded that the current natural plan shape fits the equilibrium plan shape (Hsu and Evans, 1989) which is common for rock outcrops or headland constrained soft shorelines subject to a persistent direction of approach where the rock outcrops act as control points.

- The rock outcrops which limit each of the cells act partially as groynes, protecting the adjoining area and limiting the sediment transport between cells (see Fig.7).

- Constant retreat is expected to happen in the Cloughaninchy coastal areas. This retreat appears to be parallel to the existing configuration, so it is expected that the tendency in the retreat remians constant for future scenarios. The expected coastal change maps take into account the HEFS and describe a situation based on an average wave climate in the area projected into the future for the years 2050 and 2100 where erosion rates have been obtained from the Litpack model. 


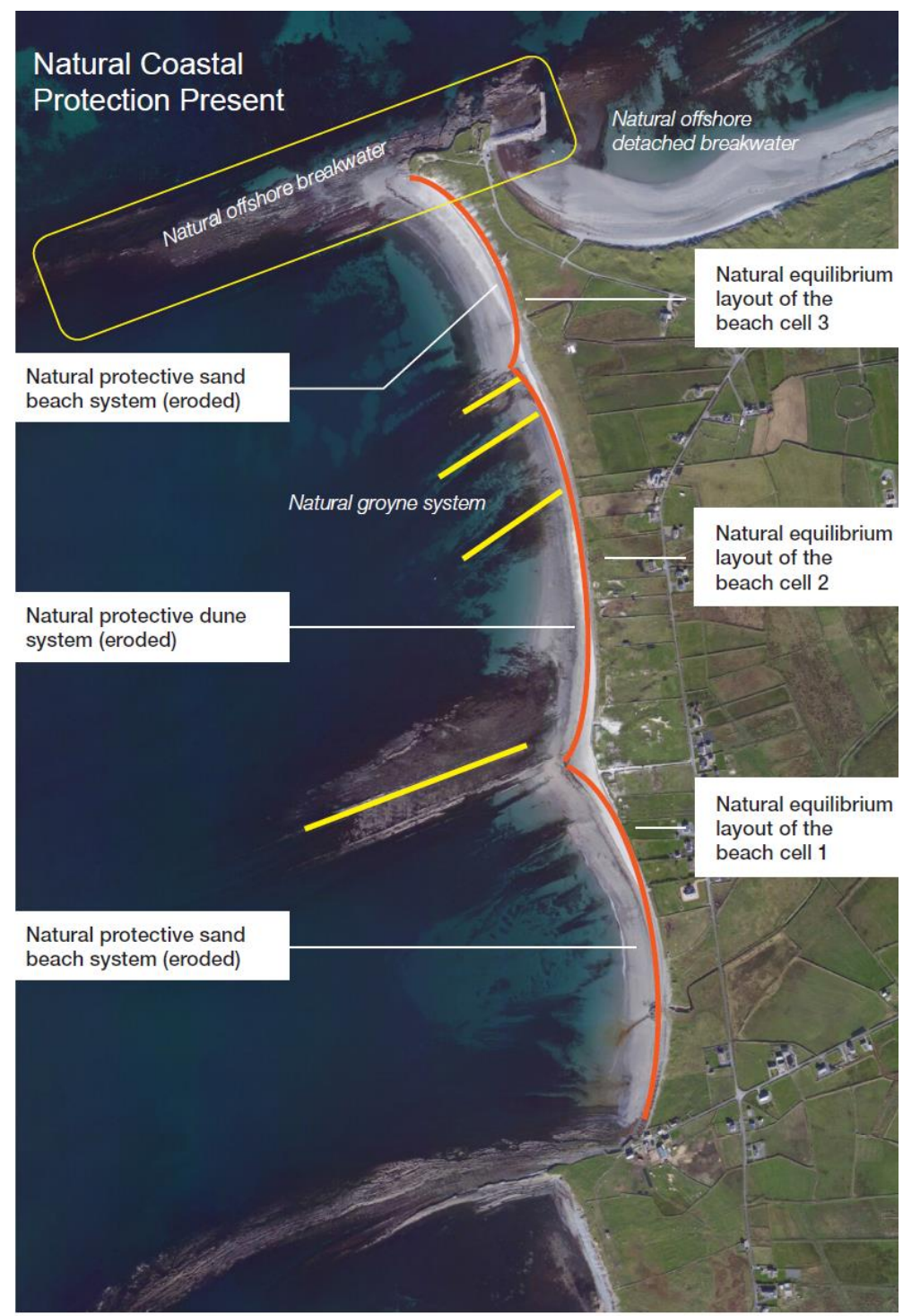

Figure 7. Coastal features at Cloughaninchy beach.

\section{Risk assessment}

Based on the numerical modelling results, both flooding and coastal erosion maps were produced for current and future scenarios including the effects of Climate Change. The maps indicated that extensive areas of the site are at risk of flooding from both tide plus surge and wave overtopping. Also, significant loss of local infrastructure is expected in the future due to erosion.

It was seen from the results that for the current scenario none of the houses at the site are at risk from the 200 year tidal flood event as they are elevated above the tidal floodplain. A number of the houses are however at risk of flooding due to wave overtopping. It was seen that waves can overtop a low point in the embankment in the northern section of the site and flood the area behind the embankment.

A number of breaches in the embankment formed during the 2014 event. When breaches of similar dimensions are included in the design runs of the model a greater number of properties are indicated as at risk from flooding. The breaches do not allow tidal ingress as the land elevation of the ground behind the breach is relatively high, but rather the breaches allow a greater volume of water from wave overtopping to flood the site.

While the houses are the key receptors at the site it is noted that extensive areas of agricultural land are at risk from both tidal and fluvial flooding. 
Critical coastal risks were identified in the areas shown in Figure 8. These risks include overtopping, erosion, breach formation and tidal flooding.

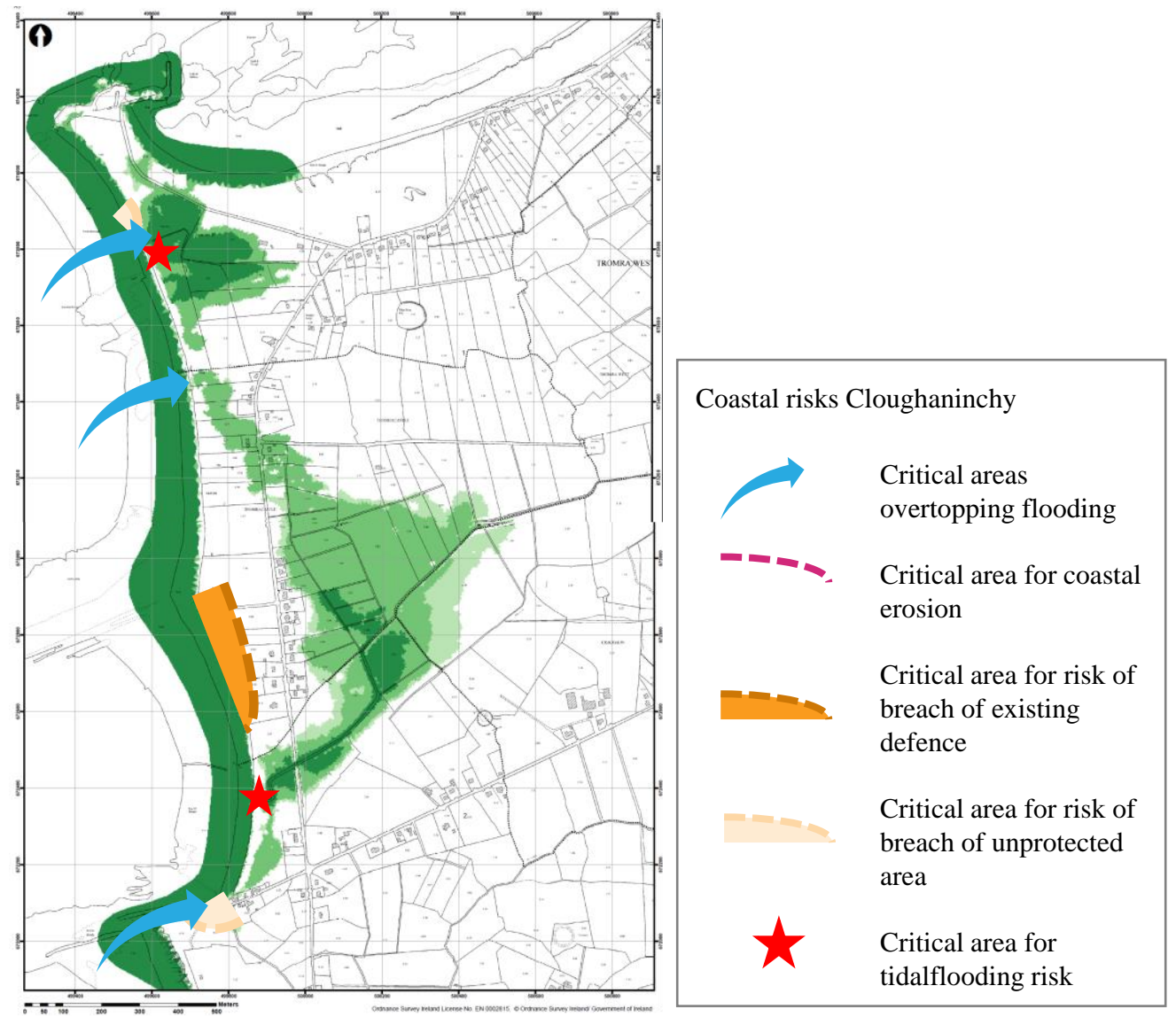

Figure 8. Critical coastal risks at Cloughaninchy.

\section{Options study}

Based on the critical coastal risks identified, a wide range of coastal protection solutions were assessed. These include: offshore breakwaters, groynes, beach nourishment, revetments, etc.

1. Assessment criteria

Following on from the preliminary options assessment the most suitable solutions for each of the three areas defined in Figure 8 were identified. The options were then assessed using a Multi Criteria Analysis (MCA). The MCA assesses each option with respect to a number of criteria. The criteria collectively address site specific applicability, risks in terms of human health and life (social), environment, cultural heritage, economics and infrastructure. The methodology used has been adapted for a coastal site from an agreed approach developed by the OPW for the National Catchment Flood Risk Assessment and Management (CFRAM) programme.

The preferred option(s) for each assessment area were selected following the MCA. The process was developed and used to ensure that the assessment of flood and erosion risk management options was evidence-based, transparent, and inclusive of stakeholder and public views.

An overall assessment of construction practicality was also undertaken taking into account complexity, site access, availability of construction material, use of plant (land or marine based) and construction duration. Consideration was given to how environmentally friendly each option is with regards to the potential damage to the environment, public perception and expected difficulties with the licensing process.

2. Scoring

The weights assigned to each criteria are shown in Table 3. Options were compared under each of the five headings; Economic; Social; Environmental / Heritage; Technical and Other. Each option was given a score of between 1 and 5 for each objective. The matrix shown in Table 4 provides an overview of the scoring regime and examples of the characteristics of defence options that would give rise to particular scores under each heading for the Cloughaninchy Coastal Protection Works. 


\begin{tabular}{|c|c|c|c|}
\hline Core criteria & $\begin{array}{c}\text { Global } \\
\text { weighting }\end{array}$ & $\begin{array}{l}\text { Individual } \\
\text { weighting }\end{array}$ & Objective \\
\hline 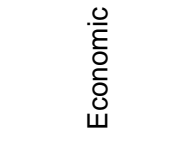 & $20 \%$ & $100 \%$ & Expenditure and maintenance cost \\
\hline \multirow{4}{*}{$\begin{array}{l}\bar{\pi} \\
\dot{0} \\
\infty\end{array}$} & \multirow{4}{*}{$20 \%$} & $30 \%$ & Minimise health and safety risk of options. \\
\hline & & $30 \%$ & Protect existing area key infrastructure. \\
\hline & & $20 \%$ & Economic activity \\
\hline & & $20 \%$ & $\begin{array}{l}\text { Where possible create new beach access and social } \\
\text { recreational and community facilities. }\end{array}$ \\
\hline \multirow{6}{*}{ 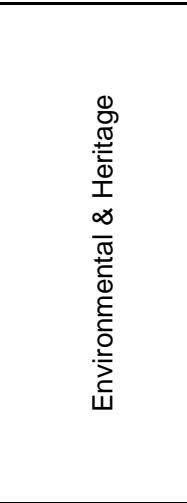 } & \multirow{6}{*}{$20 \%$} & $15 \%$ & $\begin{array}{l}\text { Safeguard and promote sustainable land use in keeping } \\
\text { with WFD, }\end{array}$ \\
\hline & & $15 \%$ & $\begin{array}{c}\text { Support the achievement of good ecological status/good } \\
\text { ecological potential (GES/GEP) under the WFD. } \\
\text { Particularly morphology as a supporting element to } \\
\text { ecological status. }\end{array}$ \\
\hline & & $20 \%$ & $\begin{array}{l}\text { Protect the flora and fauna of the area and, where } \\
\text { possible, enhance biodiversity. }\end{array}$ \\
\hline & & $15 \%$ & $\begin{array}{c}\text { Protect, and where possible enhance, landscape } \\
\text { character and visual amenity. }\end{array}$ \\
\hline & & $10 \%$ & $\begin{array}{l}\text { Protect and where possible enhance known features of } \\
\text { cultural heritage importance and their settings. }\end{array}$ \\
\hline & & $25 \%$ & Need for licencing and statutory permits \\
\hline \multirow{3}{*}{ 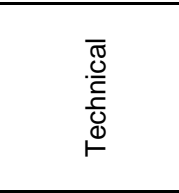 } & \multirow{3}{*}{$30 \%$} & $50 \%$ & $\begin{array}{c}\text { Appropriate design to solve the issues, operationally } \\
\text { viable and site specific }\end{array}$ \\
\hline & & $25 \%$ & $\begin{array}{c}\text { Ensure options are technically and logistically viable in } \\
\text { relation to construction }\end{array}$ \\
\hline & & $25 \%$ & Ensure options are resilient to climate change \\
\hline$\frac{\grave{\Phi}}{\stackrel{ \pm}{\Xi}}$ & $10 \%$ & $100 \%$ & Minimise impacts on adjoining areas \\
\hline
\end{tabular}

\begin{tabular}{|c|c|c|c|}
\hline \multirow[t]{2}{*}{ Topic } & \multicolumn{3}{|c|}{ Score } \\
\hline & 1 & 3 & 5 \\
\hline \multirow[t]{2}{*}{ Economic } & Expensive. & Moderate Cost. & Low Cost. \\
\hline & High maintenance. & Moderate maintenance. & Low maintenance. \\
\hline \multirow[t]{2}{*}{ Social } & $\begin{array}{l}\text { Removes /restricts existing } \\
\text { beach access. }\end{array}$ & $\begin{array}{l}\text { Maintains existing beach } \\
\text { access }\end{array}$ & $\begin{array}{l}\text { Enhances existing beach } \\
\text { access. }\end{array}$ \\
\hline & $\begin{array}{l}\text { Encroachment onto private } \\
\text { lands. }\end{array}$ & $\begin{array}{l}\text { No encroachment onto } \\
\text { private lands. }\end{array}$ & Increased protected area. \\
\hline \multirow[t]{2}{*}{$\begin{array}{l}\text { Environmental / } \\
\text { Heritage }\end{array}$} & Significant loss of habitat. & Some loss of habitat. & $\begin{array}{l}\text { Protects habitats/ cultural } \\
\text { heritage. }\end{array}$ \\
\hline & Significant visual impact. & Neutral visual impact. & Enhances visual character \\
\hline \multirow[t]{2}{*}{ Technical/ Other } & Challenging to construct. & $\begin{array}{l}\text { Moderately challenging to } \\
\text { construct. }\end{array}$ & Routine construction. \\
\hline & Reduces river conveyance. & $\begin{array}{l}\text { Maintains river } \\
\text { conveyance. }\end{array}$ & Increases river conveyance. \\
\hline
\end{tabular}


3. Proposed solutions

The preferred options are recommended as follows (see Fig.9):

Area 1 (from chainage 0 to chainage 1,300): replace and extend local repairs

Area 2 (from chainage 1,300 to chainage 1,900): replace existing revetment and repairs with new revetment

Area 3 (from chainage 1,900 to chainage 2,390): replace existing revetment and seawall with new revetment

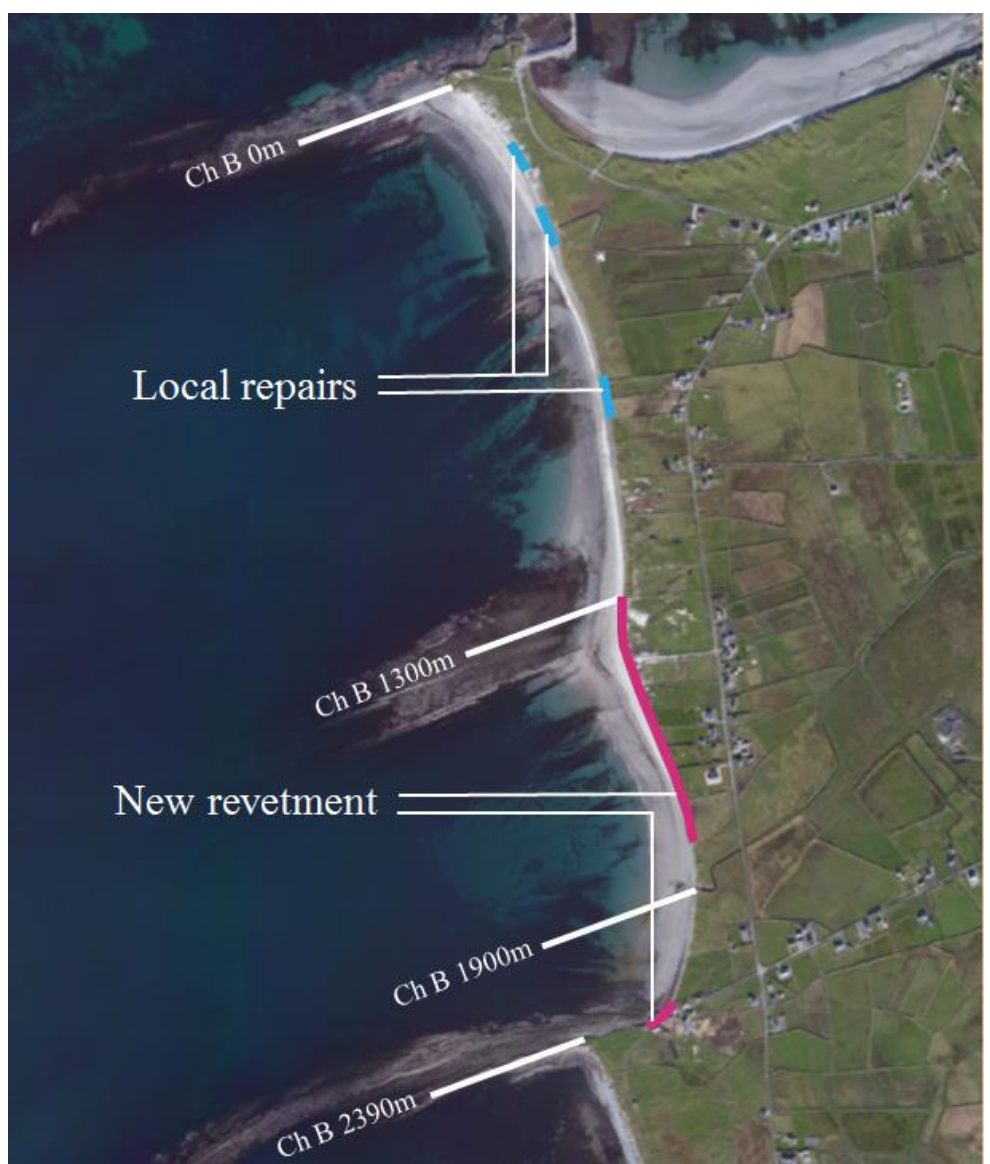

Figure 9. Coastal measures proposed.

In addition to these solutions it was recommended that the following options were implemented in the short term. These additional proposed solutions are both structural and non-structural.

- Non-structural solutions:

Dune protection in the form of appropriate fencing at the base of the dunes and inland areas to prevent access and facilitate natural regeneration.

Beach monitoring programme to be carried out annually as well as immediately following any extreme storm events.

- Additional structural measures to be taken into account are as follows:

Installation of non-return valves and inlet protection to outfall.

Reconstruction of an existing culvert in the north area since it is in a poor condition. Rock armour is needed to protect the structure from wave action and movement of shingle under storm conditions.

Improvement of the drainage system: it was proposed that some ditches are excavated in the areas behind the proposed revetment. This measure will facilitate the drainage of the areas if flooded, so the houses are not affected by direct flooding.

\section{Economic assessment of benefits and costs}

A detailed cost benefit analysis which estimated the costs of the proposed works and likely economic benefit associated with implementation of the risk management measure was undertaken. The benefit to be derived from the proposed scheme was the reduction in risk of flooding and coastal 
erosion to land and property. This risk was quantified as the expected damage that would occur over the lifetime of the scheme in terms of direct flood damages to property and infrastructure, coastal erosion with an associated loss of property and infrastructure and recreational losses associated with coastal erosion.

As per the OPW guidelines, damages to agricultural land were not included in the analysis. The damages analysis was carried out in accordance with the "The Benefits of Flood and Coastal Risk Management: A Manual of Assessment Techniques (2014)" published by the Flood Hazards Research Centre at Middlesex University.

The present value of costs was based on a 50-year design life that is capable of protecting against a 1 in 200 year flood event and coastal erosion. The cost of the scheme was calculated as $€ 3,896,000$. It was assumed that the entire cost of the scheme will be expended in a single year (2016).

The sum of these four separate present values of damages figures equals $€ 1,700,700$. This is equal to the Present Value benefits figure assuming that the residual flood damages associated with a scheme design exceedance event were ignored.

When the damages are compared with the cost of the proposed scheme it is possible to determine the associated benefit to cost ratio. Table 5 shows the results of the Cost Benefit Analysis and the associated benefit cost ratio of the scheme, which is 0.44 .

Table 5. Cost Benefit Analysis summary

\begin{tabular}{|c|c|c|}
\hline & Do Nothing Option & Preferred Option \\
\hline Present Value Cost (PVC) & $€ 0$ & $€ 3,896,000$ \\
\hline Present Value Damage (PVd) & $€ 1,700,700$ & $€ 0$ \\
\hline Present Value Damage Avoided/Benefit (PVb) & $€ 0$ & $€ 1,700,700$ \\
\hline Average Benefit Cost Ratio (BCR) & & $\mathbf{0 . 4 4}$ \\
\hline
\end{tabular}

\section{CONCLUSIONS}

The following conclusions were extracted from the study:

- The results illustrate the benefit of a multidisciplinary approach so all constraints, critical issues and interactions are studied and given ample consideration.

- The results show the need for the consideration and inclusion of overtopping and breach formation into the high-resolution modelling in order to undertake a proper assessment of flood risk.

- The results for 'future scenarios considering climate change' indicate extensive flood risk at the site highlighting the need for adequate engineering measures to address future flood and erosion risk for coastal communities.

- The Multi Criteria Analysis needs to take into consideration the particular constraints of the site to be assessed and sensitivity to the weighing of criteria must be carefully assessed.

- The results from the cost benefit analysis show the challenges of justification of investment in coastal defences with a cost benefit analysis, namely that it is difficult to justify substantial coastal defences in sparsely populated coastal communities.

\section{REFERENCES}

CIRIA Rock Manual. The use of rock in hydraulic engineering (second edition) (C683). 1991. CIRIA, CUR, CETMEF.

Danish Hydraulic Institute (DHI), An integrated modeling system for littoral processes and coastline kinetics, short introduction and tutorial, DHI Software, Copenhagen, 2015.

EurOtop manual 2007. Overtopping manual; Wave overtopping of Sea Defences and Related Structures - Assessment Manual. UK: N.W.H. Allsop, T. Pullen, T. Bruce. NL: J.W. van derMeer. DE: H. Schüttrumpf, A. Kortenhaus. www.overtopping-manual.com.

Hsu, J. R. C. and C. Evans, (1989). "Parabolic Bay Shapes and Applications". Proc., Institution of Civil Engineers, London, England, vol. 87 (Part 2), pp. 556-570.

MIKE by DHI, 2016. Spectral wave and Mike 21 Flow Model FM modules. Scientific Documentation. 